\title{
Discovery of primary exhalative hydrothermal dolostone in the Santanghu area, Xinjiang, NW China
}

The origin of dolomite has been hotly debated. There is still a lack of petrological evidence and theoretical support for the formation of primary dolomite in geological history because dolomite cannot be synthesized under normal laboratory conditions. Wright experimented with Kulong lake water under normal surface temperature and pressure conditions to precipitate dolomites. His study offered experimental petrological evidence for primary dolomite formation. However, examples of ancient primary dolomites are rare. A research group led by Professor Liu at Northwestern University discovered primary dolostone formed by mantle-originated exhalative hydrothermal activities in an intracontinental rift basin in the Permian, analogous to "white smokers" on the modern seafloor. Their study offered important evidence of primary dolomite formation in geological history (Sci China Earth Sci, 2012, 55: 183-192).

In samples taken from the Yuejingou section and drill cores taken from the Santanghu Basin (Figure 1), the dolostone in the Permian Lucaogou Formation includes laminated dolomicrite $(0.005-0.01 \mathrm{~mm}$ in size) and doloarenite $(0.01-0.05 \mathrm{~mm}$ in size, such as K-feldspar analcime dolostone, dolomitic K-feldspar analcime laminite, microcrystalline quartz analcime laminite, and algal dolostone). They are finely $(0.05-0.15 \mathrm{~cm}$ thick) interlaminated with lime micrite and dusty pyrite laminae that may be a product of black smokers. The interlaminites are probably the products of alternating hydrothermal exhalation of "black and white smokers" in the Santanghu lake. Alkali feldspar and analcime grains in dolostone are interpreted as having been derived from analcime phonolites and peralkaline igneous rocks. Some analcime grains have a tetragonal trisoctahedron crystal form with embayed edges. Alkali feldspars are dominantly sanidine and orthoclase; and orthoclase commonly encases sanidine, which, in turn, is encased by analcime. The sequence reflects sequential crystallization of peralkaline magmas. The fragments of these rocks were brought up from the subsurface by hydrothermal fluid flows. These

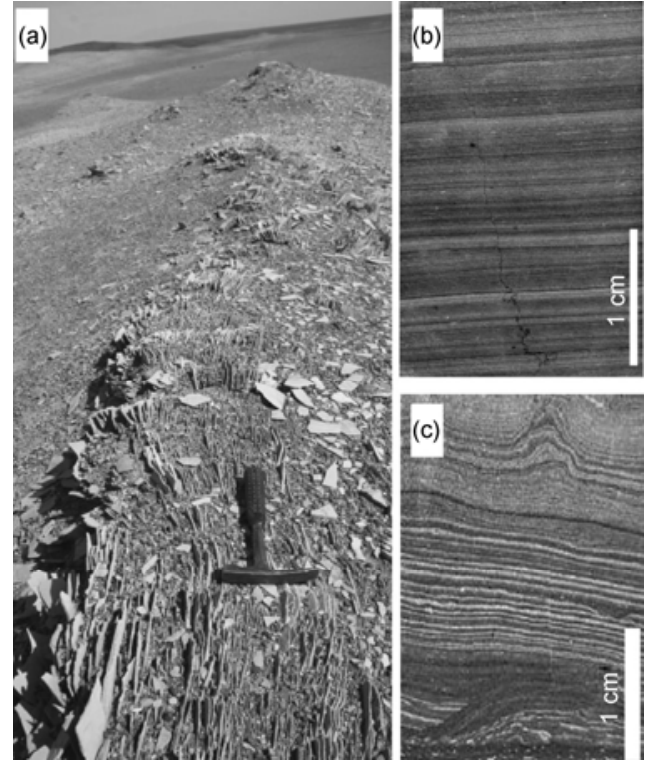

Figure 1 (a) Field photograph of steeply-dipping laminated dolostones sandwiched in weathered black laminites in Yuejingou. Hammer is $30 \mathrm{~cm}$ long. Stratigraphic-up is to the left (south). (b) Photograph of a core containing intact interlaminated white and black laminites. (c) Photograph of a core showing soft-sediment deformation, wavy lamination, and sharp and erosional bases of white and black laminites. observations suggest that the lake was sediment-starved; Lake water had a high temperature. Cathodoluminescence microscopy shows that the formation of ankerite and dolomite is earlier than that of calcite; ankerite and dolomite do not coexist, suggesting variable iron content in hydrothermal fluids. The ${ }^{87} \mathrm{Sr} /{ }^{86} \mathrm{Sr}$ ratios of 10 dolostones are $0.70457-0.706194$, and 0.705005 on average, which are similar to the global average (0.70350). All doloarenite samples have a significantly negative $\delta \mathrm{Eu}$ anomaly and a very weak positive $\delta \mathrm{Ce}$ anomaly. The composition is similar to that of hydrothermal exhalative rocks with the mixing of lake water, and is somewhat similar to that of the overlying Tiaohu basalts. In summary, the Santanghu dolostone is interpreted as being primary and having been produced via mantle-originated hydrothermal activities. The fluid from the upper mantle caused the serpentinization of ultramafic rocks that intruded into the lower crust to obtain $\mathrm{Mg}^{2+}$ and $\mathrm{Fe}^{2+}$, and injected the ions into the lake water as the $\mathrm{Mg}$ and $\mathrm{Fe}$ sources for dolomite and ankerite. Hydrothermal fluids associated with peralkaline magmatic rocks also provided $\mathrm{Ca}^{2+}, \mathrm{Mg}^{2+}, \mathrm{Fe}^{2+}$, and $\mathrm{CO}_{3}{ }^{2-}$. Explosive breccias formed and dolostones were convoluted near the vent of hydrothermal fluid exhalation, whereas laminated dolostones formed farther from the vent.

The dolostones are primary dolomite deposition in an intracontinental rift basin and associated with mantle-originated hydrothermal fluids. They provide an insight into the origin of dolomite formation in the geologic history and clues to understand the sedimentary environments and tectonic conditions in northern Xinjiang during the late Paleozoic.

See the article: Liu Y Q, Jiao X, Li H, et al. Primary dolostone formation related to mantle-originated exhalative hydrothermal activities, Permian Yuejingou section, Santanghu area, Xinjiang, NW China. Sci China Earth Sci, 2012, 55: 183-192

Open Access This article is distributed under the terms of the Creative Commons Attribution License which permits any use, distribution, and reproduction in any medium, provided the original author(s) and source are credited. 